\title{
The Prose Poetry Project: an introduction and five vignettes
}

The Prose Poetry Project (PPP) is comprised of a group of people who, working independently and collaboratively, focus on writing rather than analysing prose poems. Because of this, and because the PPP emerged out of practice and not out of scholarship, they have not paid much (explicit) attention to discussions about the definition of the prose poem, the structure of prose poems and what form can be considered poem rather than prose or fiction.

The PPP emerged in late 2014, when several members of the International Poetry Studies Institute - Paul Hetherington, Paul Munden and Monica Carroll - began to email prose poems to each other in a playful exchange of poetry. By January 2015, Jordan Williams and Jen Webb had joined in the game, and shortly thereafter Paul Hetherington began inviting other poets to participate. By June 2015 the group included Jennifer Crawford, Cassandra Atherton, Owen Bullock, Shane Strange, Julian Stannard, Anne Caldwell, Ross Gibson, Andrew Melrose and Lucy Dougan. By early 2017 they had been joined by Oliver Comins, Carrie Etter, Niloofar Fanaiyan, Stephanie Green, Charlotte Guest, Oz Hardwick, Penelope Layland, Rupert Loydell, Nigel McLoughlin, Alvin Pang, Maggie Shapley and Dominique Hecq.

At the time of writing, with those additions and some withdrawals, the Prose Poetry Project comprises 20 poets from across Australia, Israel, Singapore and the UK. For this Special Issue on prose poetry, the editors invited members of the PPP who live outside Australia to contribute a vignette on the writing of prose poems. Five vignettes are included here: Anne Caldwell's on place and landscape; Oz Hardwick on games, the quotidian, and practice; Rupert Loydell's outline and explanation of the prose poetry course he would like to teach; Andrew Melrose's description of how this collaborative practice can both spark new poems and generate different art forms (in this case, song lyrics); and Alvin Pang's approach to the prose poem, which combines play with the building of 'stanzas' (clusters of text, forming 'rooms')

Elsewhere in this Special Issue is included a poem by each member of the PPP, drawn from one of the three PPP anthologies that have been published to date. ${ }^{1}$ These anthologies were compiled from the poems written each year - itself a substantial task, since nearly 3,000 poems have been drafted since November 2014. As well as these anthologies, several chapbooks or full collections have emerged, ${ }^{2}$ and PPP poems have also appeared in journals and in other collections. In addition, scholarly publications are being published ${ }^{3}$, and a specialist press - Recent Work Press - has emerged to publish both prose and lineated poetry. What all this 'product' attests to is the generative force of this approach to the writing of poetry; and to the affordances of collaboration and play for creative work.

\section{Endnotes}

1. The anthologies produced to date, all published by Recent Work Press in Canberra, are: Seam: Prose Poems, edited by Shane Strange (2015); Pulse: Prose Poems, edited by Shane Strange 
and Monica Carroll (2016); and Tract: Prose Poems, edited by Monica Carroll and Paul Munden (2017).

2. Examples include three collections published by Recent Work Press under the Authorised Theft imprint: Pegs Jars Keys Gaps Nets (2015); Taoist Elements (2016); and Colours (2017). Each collection contains five chapbooks (each of 21 poems), along with a colophon that contains biographical notes, research statements and contextualising mini-essays. Cassandra Atherton, Paul Hetherington, Paul Munden, Jen Webb, and Jordan Williams are the poets who have contributed each year to date.

3. Other PPP-derived collections include Monica Carroll's Isolator (2017), and Jen Webb's Sentences from the archives (2016). Some of the scholarly outputs produced by members of the PPP include:

Atherton, Cassandra and Hetherington, Paul 2016 'Like a porcupine or hedgehog?: The prose poem as post-romantic fragment', Creative approaches to research 9.1: 19-38

Atherton, Cassandra and Hetherington, Paul 2016 'The prose poem as Igel: A reading of fragmentation and closure in prose poetry', Axon: Creative explorations, Capsule 1: Poetry on the move 2015, http://www.axonjournal.com.au/issue-c1/

Atherton, Cassandra and Paul Hetherington 2015 'Unconscionable mystification? Rooms, spaces and the prose poem', New writing 12.3: 265-81

Atherton, Cassandra, Shane Strange, Jen Webb, Jen Crawford, Owen Bullock and Paul Munden 2016 'The Prose Poetry Project', Axon: Creative explorations, Capsule 1: Poetry on the move 2015, http://www.axonjournal.com.au/issue-c1

Hilhorst, A and Paul Hetherington 2016 'Prose poetry and painting with words: In conversation with Paul Hetherington', Westerly 61.2: 160-168

Hope, Cathy, Paul Hetherington and Bethaney Turner 2017 'Playful seriousness and serious play: Poetry as creative practice in the international prose poetry project', TEXT Special Issue 40: Making it new: Finding contemporary meanings for creativity (April), http://www.textjournal.com.au/speciss/issue40/Hope\&Hetherington\&Turner.pdf Strange, Shane 2016 'Prose poetry as meeting place', Axon: Creative explorations, Issue 10: The Poetics of Collaboration (April), http://axonjournal.com.au/issue-10/prose-poetrymeeting-place. 


\title{
University of Bolton
}

\author{
Anne Caldwell
}

\section{Crossing borders}

\section{Biographical note:}

Anne Caldwell is a freelance writer, a lecturer in creative writing for the Open University and a PhD student of creative writing at the University of Bolton, UK. She is the author of three collections of poetry. She worked for the National Association for Writers in Education in the UK for over ten years. Her latest poetry collection is Painting the Spiral Staircase, Cinnamon, 2016.

Email: anne.caldwell@open.ac.uk;_Blog http://annecaldwell.net; Twitter @caldwell_anne

The prose poem below was written as part of the IPSI prose poem project, hosted by the University of Canberra. I am a member of this group of writers and I have found that the process of collaboration gives me the confidence to experiment with a stronger, more political voice in my work, responding to current events as they occur. I feel part of an international community, and a poet who now has a collegiate readership. The prose poetry form also has endless possibilities. I am therefore able to take more creative risks in my work, and experiment with larger themes and ways of writing that mark a departure from my previous poetry collections.

\section{Crossroads}

After Brexit, the crossing of barriers of all kinds became important. Straddling, hurdling, hanging votives on fences, cutting through wire or hammering concrete. Her mother had been at Greenham and wove Suffragete-coloured ribbons into the barrier surrounding the air base. Her father had worked in Berlin when the wall was punched through and the sky was brimming with freedom, firecrackers and laughter. She'd once tried to find a check-point in the wall in Belfast. It snaked its poisonous route through back gardens and yards, past murals of masked men and curbstones painted red, white and blue.

Any wall begins in the mind, but the mind and heart can dissolve this hardening, just as salt crystals or honey dissolve into water, soothing our throats, making our voices louder and more sonorous in tone.

This subject is suited to the prose poetry form because it examines the concept of transgressing borders, mirroring the way that prose poetry can inhabit the hybrid 
space between fiction and poetry. In a paper in New Writing, Paul Hetherington and Cassandra Atherton suggest the form is:

Janus-faced, looking forwards and backwards, understanding transitions, providing passages and doorways. Space opens before and behind ... it understands both prose and poetry and it comfortably inhabits the space between them. (Atherton and Hetherington 2015)

I have taken this concept a step further in my own creative research by examining the relationship between the prose pose and a sequence of photographs. This work has a sense of place as its focus. I have begun to explore the space that exists between works and images in order to understand my creative process in more depth.

This work explores the influence of human land use in a once-wild stretch of moors in the north of England. I discovered 'found' text: depicting barriers, instructions, warning signs and litter. The work highlights a number of themes, such as lack of access, freedom to roam and ecological issues in this landscape.

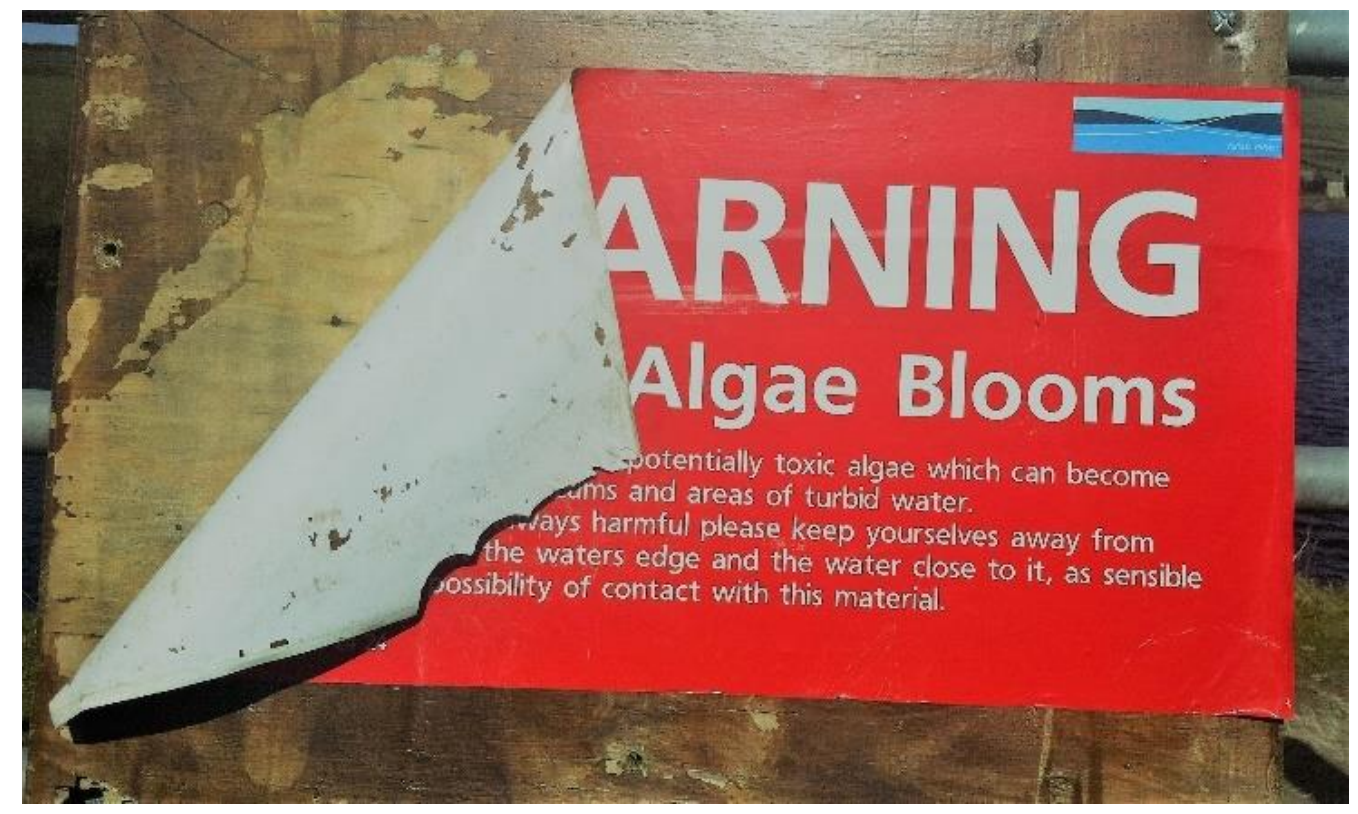

Figure 1. Photostory - Algae bloom on the water, Anne Caldwell

For example, I realised that the text in the photograph and my prose poem 'Crossroads' complemented each other in unusual ways. I juxtaposed the image above with a phrase describing the wall that separates Catholics and Protestants in the city of Belfast, Northern Ireland: 'it snaked its poisonous route through back gardens and yards, past murals of masked men and curbstones painted red, white and blue'.

The wall becomes a more powerful, visual metaphor. The 'poison' of sectarian violence resonates with the idea of toxic algae blooming on a reservoir. The Union Jack, Loyalist colours of the curbstones in Northern Ireland (painted to signal allegiance to England in the Protestant, Shankill Road District), are echoed in the red, white and blue of this warning notice to bathers and walkers. 
On a wider note, I realised that the prose poetry that I am writing as part of my current research examines the urbanisation of the landscape in which I live. This theme has a rich literary and visual history. Margaret Drabble, writing about the photography of Fay Godwin in The Guardian, commented on how the British countryside was becoming more fenced in:

Our common land would be the copyright of others. We are fortunate that [Godwin] made her journeys round the British Isles when she did, before even more of our landscape was fenced off or built up. Philip Larkin, in a poem titled 'Going, going', oddly enough commissioned by the then Department of the Environment, gloomily concluded that

... before I snuff it, the whole

boiling will be bricked in

except for the tourist parts -

first slum of Europe ...

It hasn't happened yet, but, as Godwin and Larkin warn us, it may. (Drabble 2011)

Through my own creative processes of writing prose poetry and taking photographs, I have discovered how prophetic this work by Godwin and Larkin has become. The prose poetry form itself is a flexible space in which I can examine the political themes of wallbuilding, or fencing in a landscape. I am particularly interested in how the prose poem, with its tight frame, can gesture to a wider sense of place; real or imaginary. Furthermore, taking part in the Prose Poetry Project has opened up a rich, international dialogue across linguistic borders. I echo the thoughts of Hope, Hetherington and Turner, writing in TEXT in 2017: the process has become for me a playful, collaborative space in which to experiment.

\section{Works cited}

Atherton, Cassandra and Paul Hetherington 2015 'Unconscionable mystification? Rooms, spaces and the prose poem' New writing 12, 3: 265-281

Drabble, Margaret 2011 'Fay Godwin at the National Media Centre' The Guardian (8 January) at https://www.theguardian.com/artanddesign/2011/jan/08/margaret-drabble-fay-godwin (accessed 25 May 2017)

Hope, Cathy, Paul Hetherington and Bethaney Turner 2017 'Playful seriousness and serious play: Poetry as creative practice in the international prose poetry project' TEXT Special Issue 40 'Making it new: Finding contemporary meanings for creativity' at http://www.textjournal.com.au/speciss/issue40/Hope\&Hetherington\&Turner.pdf (accessed 25 May, 2017) 


\title{
Leeds Trinity University
}

\author{
Oz Hardwick
}

\section{Playing in the prose poetry garden}

\begin{abstract}
Biographical note:
Oz Hardwick is a poet, writer, photographer based in York (UK). In the guise of Prof Paul Hardwick, he is Programme Leader for Creative Writing at Leeds Trinity University, where he also teaches Medieval Literature. Most of the time, these conjoined identities get along just fine.
\end{abstract}

Sleep tastes like earth, like dandelions, bitter and gamey. ${ }^{1}$

Mornings are a seesaw of ritual and chance: breakfast; cat's breakfast; let the cat out; let the cat in; ablutions; let the cat out; dress; let the cat in; let the cat out; and so on. At some point, I will open my email account and read the prose poems which will have arrived during the night - some of the more active participants in the Prose Poetry Project being in Australia, I pick up after the main flurries of activity - and, as my body wakes up and goes about its automatic tasks, my mind will set about ordering itself for the day, guided in one direction or another by the contents of my inbox, like honeysuckle twining around a trellis.

It's weeks since I arrived here and my packing cases haven't arrived yet, so I've built a nest of twigs and newsprint.

Mornings are a tidy lawn bordered by a tangle of overgrown shoots and stems: a maze of growing ideas searching for sun and shape. My cat weaves in and out of the Lonicera (family Caprifoliaceae), pawing doodles along margins, leaping to catch a butterfly, a shadow, or a ball my father threw gently half a century ago, which I turn to catch. Play takes place, as Huizinga notes, within a space 'marked off beforehand either materially or ideally, deliberately or as a matter of course'; that is, it occurs by mutual consent of participants within 'temporary worlds within the ordinary world, dedicated to the performance of an act apart' (Huizinga 1949: 10).

I read myself awake on old TV listings, doing my best to avoid pictures of the war.

Mornings are a handful of dice that won't stop rolling, their possibilities incalculable, like the Big Bang viewed as a snooker break, with each ball initiating its own infinite chain reaction, or a cat on a baize lawn contemplating the ghost of the moon, licking its milk from the day's rim. These games are forms of pleasure and amusement that are 'designed experiences; they model behavior and imply intent from players ... [while 
having] identifiable rules within a contained system' (Patterson 2015: 7). Before leaving for work, I quarter the garden like a neat handkerchief and slip it into the same pocket every day, though may not remember it when I need it.

When I'm hungry, I burn it all, cook my excess fat, swallow myself with my eyes closed, the reek of burnt tallow prickling tears.

Mornings are a tentative unfolding, a scent of past flowers. 'By the late Middle Ages the garden, like the fountain and the castle, was an unreal space of nostalgia' (Camille 1998: 76), and my train has been running up and down the Harrogate line since 112 years before I was born, passing Knaresborough Castle, built c.1100. At Starbeck Station a black cat sits on the platform, eyeing a sparrow, though the Bestiary tells us that 'The cat (musio) is so named because it is inimical to mice (muribus)' (Clark 2006: 161). Being written may render something true, but can't make it factual. Everything mulches down to compost, and 'ideas start to grow' (Patchett 2014: 40-41).

I season my meals with ticking clocks, an accumulation of spiders' eggs, the murmur of passing cars, but they still taste of sleep.

Mornings are a slow waking, my thoughts learning themselves anew, lacing themselves into tight-fitting words, checking their reflections in a prose poem by someone I have only met fleetingly, if at all. Chances are, the poet's as asleep as my cat, ginger on the grass-green sofa. Within the patchwork distractions, something neat takes shape, and 'inside the play-ground an absolute and peculiar order reigns'. Play 'creates order, is order' (Huizenga 1949: 10). Through the train window, there is the scent of honeysuckle. In the office, I'll sip another coffee, playing for time: press Send. The world's going mad: 'Il faut cultiver notre jardin' (Voltaire n.d.: 171).

\section{Endnotes}

1. The italicised lines throughout constitute a prose poem written on 3 December 2016, responding to a prose poem by Alvin Pang.

\section{Works cited}

Camille, Michael 1998 The Medieval art of love: objects and subjects of desire New York: Harry N Abrams

Clark, Willene B (ed and trans) 2006 A Medieval book of beasts: the second-family bestiary. Commentary, art, text and translation Woodbridge: Boydell \& Brewer

Huizinga, Johan 1949 Homo ludens: the play element in culture London: Routledge \& Kegan Paul

Patchett, Ann 2014 'The getaway car: a practical memoir about writing and life' in This is the story of a happy marriage London: Harper Perennial, 19-60

Patterson, Serina 2015 'Introduction: setting up the board' in S Patterson (ed) Games and gaming in Medieval literature New York: Palgrave Macmillan, 1-20

Voltaire (undated) Candide ou l'optimisme Paris: Edition Jules Tallandier 


\title{
Falmouth University
}

\author{
Rupert Loydell
}

\section{The untaught module}

\section{Biographical note:}

Rupert Loydell is Senior Lecturer in the School of Writing and Journalism at Falmouth University, the editor of Stride magazine, as well as a writer, publisher and artist. Shearsman recently published Dear Mary, a book of poems about Italy, colour, art, and annunciation; other critical writing has appeared in Punk \& Post-Punk, Journal of Writing and Creative Practice, New Writing and Journal of Visual Art Practice.

Whether one regards prose poetry as poems that use everything except lineation or as poetic prose, it remains difficult to define, despite the growth in popularity of the form (or forms), as evidenced by the number of anthologies in the last twenty years, and how the prose poem is now an established and accepted part of many poets' work.

One of the disappointments I have had in the last decade, having published two prose poem anthologies (one of which I co-edited) and contributed work to others, was writing and successfully validating a prose poem module at Falmouth University that somehow never made it into the timetable before our degrees had to be rewritten. What this enabled me to do, however, in lieu of formulating a definition, was to think about how to categorise prose poems, and to facilitate the study and writing of them. What topics or themes were appropriate? What processes and forms useful?

I tend to teach with a wide range of material, rather than focusing on one text in detail, allowing for comparison between texts, as well as dialogue between students and texts, and discussion between students. So I decided to start with a week tracing the development of the prose poem from Baudelaire, Mallarmé and twentieth-century Modernists, followed by a week considering post-World War 2 and contemporary prose poetry. (That word contemporary would allow me to use anything recent, and as exciting as I wanted!)

Further weeks would be spent considering texts umbrella-ed under titles such as 'Parables and Fables', 'Journals and Diaries', 'Object and Analogue', 'Travelogues', 'Meditation and Contemplation', 'The Haibun', 'Documentary', 'List and Found' and 'Short Short Fiction', encouraging engagement with a wide range of authors both critically and as models for writing workshops. Students would have to write an essay 
and a coherent portfolio of prose poems, not just a gathering of workshop pieces, for their final assignment.

I looked forward to using Beckett's and Borges' short fictions, and Robert Lax's journals; to comparing Alice Oswald's pastoral navigation of the River Dart with Brenda Coultas' daily exploration of the Bowery in Manhattan; and to introducing students to David Jones' difficult and somewhat neglected work. To consider how John Taggart recreates Rothko's paintings in words and also writes about his own work; how John Ashbery and Sheila E Murphy reinvented the haibun in American English; how McKenzie Wark's grid-referenced socio-geopolitical texts could be considered poems. But it was not to be.

One of the interesting anthologies of prose poems I discovered was Kempher's Always the Beautiful Answer, which gathers up 'Some Helpful Definitions \& Discussions' before moving to a section which considers 'Some History - The Innovators'. The rest of the book considers three poets in some detail before offering some 'Borderline Cases' and a surprising gathering of contemporary poets. Just as interesting as the poems themselves are the short introductory notes that many authors offer about how and why they write, an informal poetics I thought my students would benefit from reading.

The other must-have anthology that I decided would also be a set text for my students was Clements and Dunham's An Introduction to the Prose Poem, which uses a similar but different set of headings to gather up poems. As well as overlapping with some of my titles it offered 'Anecdote', 'Repetition', 'Rant', 'Dialogue' and 'Essayistic' works, as well as 'Prose Poems About Prose Poems'. This parallel but differing approach would allow students a wider and different take on the prose poem, and also offer them a generous number of examples for use in both their essay and the seminar presentation each would be asked to give.

Of course, since our degrees were rewritten and then rewritten again, I have used many of these texts in different teaching contexts, be that poetry, creative nonfiction, or a recent module to do with mash-up, collage, recycling and writing back to what we read, but part of me still wishes I'd been able to teach the module I spent time planning and researching, on the back of my own, continuing, interest in and use of the form.

\section{Towards a Definition}

Prose-poetry is when a person behaves differently from what is considered normal and realizes they have stepped into someone else's arms, someone who is as much in control of the world as they are.

It is a place where language is all compression and angle; tautness; a signpost to a different meaning. It is a key to a house with no doors, to a library full of books you want to read but must use to stoke the fire - for otherwise there is no warmth. 


\section{Works cited}

Clements, B and J Dunham (eds) 2009 An introduction to the prose poem Danbury, CT: Firewheel Coultas, B 2003 'The Bowery Project' in A handmade museum Minneapolis: Coffee House Godbert, G (ed) 2002 Freedom to breathe: Modern prose poetry from Baudelaire to Pinter Exeter: Stride

Kempher, RM (ed) 1999 Always the beautiful answer: A prose poem primer St Augustine, FL: Kings Estate

Lax, R 1996 Love had a compass. Journals and poetry New York: Grove

Loydell, R and Miller, D (eds) 1996 A curious architecture: A selection of contemporary prose poems Exeter, UK: Stride

Murphy, SE 1987 With house silence Exeter, UK: Stride

Taggart, J 1994 'A preface’ in Songs of degrees. Essays on contemporary poetry and poetics Tuscaloo: University of Alabama

Taggart, J 2010 'Slow song for Mark Rothko’ in Is music: Selected poems Port Townsend, WA: Copper Canyon

Wark, M 2002 Dispositions Cambridge: Salt 


\title{
University of Winchester
}

\author{
Andrew Melrose
}

Where 'falls the shadow...' and 'The sound of snow falling': a prose poem at the beginning of a different journey

\section{Biographical note:}

Andrew Melrose is Professor of Writing at the University of Winchester, where he writes fiction, nonfiction, academic chapters and articles. He is currently completing the book Writing Song Lyrics with Glenn Fosbraey (Palgrave 2017), and has contributed to the Prose Poetry Project anthologies published by Recent Works Press.

I have often wondered about these lines from TS Eliot's 'The Hollow Men'

$$
\begin{aligned}
& \text { Between the idea } \\
& \text { And the reality } \\
& \text { Between the motion } \\
& \text { And the act } \\
& \text { Falls the Shadow. }
\end{aligned}
$$

Every now and then they cross my mind, especially when I am ruminating on words and ideas, and getting the feeling they are taking shape, becoming something more than mere air. What is the shadow that falls between the idea and the reality, between the motion and the act? For me it's that point when the artist asks, what am I going to make of this thing, this idea, this fragment of thought floating around inside my head? Will it become an objet d'art, a piece of sculpture, a picture, a poem, a song? That's what I want to talk about here: the point at which the artist or poet or writer decides what is to be made in response to the idea; when the shadow begins to take shape. Edward Hirsch writes:

I remember once walking through a museum in Athens and coming across a tallstemmed drinking cup from ancient Greece that has Sappho saying, 'Mere air, these words, but delicious to hear'. The phrase inscribed into the cup, translated onto a museum label, stopped me cold.

Her lines, he continues, 'have a lapidary quality. The phrase has an elegance suitable for writing, for inscription on a cup or in stone, and the writing fixes the evanescence of sound. It holds it against death' (Hirsch 1998-99). 
Writing words down, inscribing them on a cup or on stone, putting them in a painting, including them in an installation: there are many ways to hold words against death after they have been uttered. That is the first task, though it doesn't always seem to come first time.

I am involved in the IPSI Prose Poetry Project, and while it has taken me out of some comfort zones it has also provoked and promoted ideas that help me to develop outcomes in different categories. The way we interact with the prose poem project means that sometimes a series of prose poems will pick up on a thread and ideas bounce around from person to person, each riffing off the other's work. In the case I am going to discuss, Oz Hardwick wrote these lines:

And when you look up, you see a young girl in a white blouse and striped tie, hair like ropes and ivy, waving to you, waving to a stranger, waving to passing ships, and singing, loud, but out of tune. (05-Feb-2017 03:36 a.m.)

I caught the tail end of the 'waving to a stranger, waving to passing ships, and singing', in my mind's eye and immediately responded with:

A house with walls, a secure roof, a warm bed and a safe place to cry; a quiet night, a happy song, a calming voice on the radio and a safe place to sigh; a soft touch, a human kiss, a stroking hand and a safe place to live and love; somewhere so basic it scarcely needs explaining; we're not crossing oceans to cross you, we're just hoping ... (05-Feb2017 07:16 p.m.)

I wasn't happy with it as a prose poem, but before I scrapped it I had another go at it; and then a tune began forming and I realised it wasn't a poem at all.

Song lyrics are not poetry because they are words taken elsewhere for other purposes than literature. However, it can also be said that while not all poetry is lyrical, lyrics can be poetic. This is partly because lyrics use the devices of poetry including, where appropriate, rhythm and rhyme. So although there is a very close relationship between song lyrics and poetry there is a distinction. My prose poem then became 'The sound of snow falling':

A house with walls and a bed, somewhere safe a place to cry, a sloping roof to keep out the rain, maybe a radio and a photograph of you.

A house with laughter and a song, somewhere safe to live and love, windows and a door, a rug on the floor, maybe a radio and a photograph of you.

A safe place to sigh and cry if we like, a place to be quiet and still - listening to the quiet sound of snow falling.

No more oceans to cross, no burning bridges in the night, just a safe place to live and love, maybe a radio and the quiet sound of snow falling.

Song lyrics are not poetry and this is not a poem. A poem is a literary work; here the words are tied to the music and to the performance and then to the listener in a 
completely different artform. As John Berger wrote, 'A song, when being sung, acquires a body. And it does this by taking over and briefly possessing existent bodies' (2016: 95). Here is my performance of 'The sound of snow falling'; it no longer belongs to me.

\section{Works cited}

Berger, John 2016 Confabulations London: Penguin

Hirsch, Edward 1998-99 'Mere air, these words, but delicious to hear' Thumbscrew 12 (Winter): 3940 at http://www.poetrymagazines.org.uk/magazine/record.asp?id=12188 (accessed 1 July 2017) 


\title{
RMIT
}

\author{
Alvin Pang
}

Many things at once: my affair with prose poetry

\section{Biographical note:}

Alvin Pang is a poet, writer and editor based in Singapore. Active internationally in literary practice, his writings have been published worldwide in more than twenty languages, including Croatian, Macedonian, Slovene and Swedish. A Fellow of the 2002 Iowa International Writing Program, he serves on the board of the University of Canberra's International Poetry Studies Institute. Among various engagements, he is editor-in-chief of a public policy journal, and a doctoral candidate in the practice of creative writing with RMIT University. Author of several volumes of poetry and anthologies of Singaporean literature, his recent books include When the Barbarians Arrive (Arc Publications, Tormorden UK, 2012), UNION: 15 Years of Drunken Boat I 50 Years of Writing from Singapore (Ethos/Drunken Boat 2015), När barbarerna kommer (Rámus Forlag, Sweden, 2015), and WHAT HAPPENED: Poems 1997-2017 (Math Paper Press, 2017).

Sometime in early 2003 I came across a work by the Spanish poet and writer Rafael Pérez Estrada, 'Tattoos'. Referred to as vignettes, the work consisted of a series of short prose fragments, each about a paragraph long, each featuring the same core trope (a tattoo) and milieu (Shogunate-era Japan), yet each a selfcontained little narrative, with its own wit, evocative imagery, mystery, point of view.

At once fascinated, I took them to be something I wanted to write more of myself. I had at that point largely (but not exclusively) written and published what might be regarded as conventional verse, with line breaks at various meaningful intervals. I soon experimented with a string of what I called, quite uncritically, prose poems: each a series exploring a particular subject from a range of different contexts (as diverse as I could make them); each a multiverse drawn together into loose orbit by a thematic title ('Our Houses.' 'Se7en.' 'Taste.' 'Loaded.' 'Earshot.').

What first attracted me to these articulations was a sense of play (and playful duplicity; the practical joke): mischief made of the earnest prose narrative (often a stern faux Victorian formality, or bathetic reportage), as well as of expectations 
of poetic form and language (prosody, lyricism, a certain procedural flow from start to volta to close).

The serial form also seemed to afford a sense of compound vision; loose ends tied together by a stated theme; each paragraph/stanza/vignette a different take on an ambiguous, multifaceted topic; each series defining the territory around a particular trope and tracing a field of possibilities surrounding core meanings never quite approached directly. In doing so, they also make the case that each component perspective - including the local, the quotidian, the wry, but also the fantastic and the speculative - contributes to our understanding of an examined whole, in the way dots or lines on a blank page might, given sufficient numbers, delineate a shape: a cluster of meaning clarified not by sharp boundaries but by its inherent possibilities played out over time/space.

Why not call them poems? Stanza is after all Italian for 'room', and these are indeed houses comprised of different rooms, wrought in prose, each selfcontained but each directed towards expressing a facet of the whole. I have less interest in splitting hairs between micro-/flash fiction and prose poetry, or twitter verse. Social media (not just Twitter but the stub-friendly Facebook post) has encouraged the proliferation of memeready quips in largely paragraph form, and the format has already served to blur traditional genre boundaries or render them moot. There is perhaps something about poetry leaning on the image more heavily than on narrative for its energies, but it all depends on what is actually written, which can serve and sip from both.

Indeed, might the prose poem serve as a yet more compressed iteration of poetry? If the conventional poem (unlike prose fiction) can do away with a need to build up narrative or syntactical context to support meaning, then perhaps the prose poem can do the same but even more efficiently, by doing away with the spatial and temporal profligacy of the line break or other performative trappings of poetic endeavour. The prose poem may lose, for instance, the punctuative function of the line break, but could gain in turn a different momentum; a coy coil around the

Many of these earlier prose poems, or vignettes, or what-have-you, quickly found publication: in Softblow (http://softblow.org/alvinpang), in The Wolf (http://www.wolfmagazine.co.uk/18toc.php), and in my 2012 collection When the Barbarians Arrive (Arc: UK, 2012). And then there are the prose portraits that constitute What Gives Us Our Names (Math Paper Press: Singapore, 2011) which stem from a different impulse but should perhaps be considered alongside these shorter stabs. So too my short, Twitter-friendly iterations of this technique that I experimented with a few years ago (in duet with seasoned tweeter-scribes Teju Cole and George Szirtes).

Later prose poems, such as 'Portrait, Landscape' (first published in Australian Poetry Journal 2.1: Technology, 2012) and then Other things and Other Poems (Brutal: Croatia, 2012) take the concept of compounding perspectives to much greater extremes; they eschew even naturalistic narrative coherence or direct thematic association in favour of suggestive, evocative, imagistic possibilities. My current poems tend in this direction, including what I've been writing for the University of Canberra's ongoing Prose Poetry Project, since participating in September 2016. unsuspecting reader's attention (so often attuned in modern times to be suspicious of 'verse'); a serpentine strategy to get a grip around meaning, from the flanks. Each vignette could serve as shorthand for an entire worldview; enough of a 
sketch to make the point, not to bog one down. Best of both genres. The trick being to be both precise and concise.

My current interest is in using the prose poem as embedded cluster, clutch (not series per se, which still implies sequence and linearity). I am now trying to write prose poems that contain within a full unit (a 'paragraph'?) the range and compound energy of a whole bundle - compressing what I used to do in a paragraph into a sentence, and what I used to do in a series of vignettes into a single paragraph prose poem. Compound, but compact. Packed plurality. Words pinned but spinning, on the aerial plane of the page.

\section{Works cited}

Estrada, Rafael Pérez 2003 'Tattoos' trans Steven J Stewart Harper's magazine 307 (September, Fall/Winter): 25
A recent set of prose poems, seeking to express compound histories and perspectives on my home city of Singapore in some of the ways I've outlined in this essay, appears in the anthology Cities: Ten Poets, Ten Cities (eds. Hetherington, P \& S Strange, Canberra: Recent Work Press, 2017).

Here's one:

\section{$1.311153,103.794883(1998-2015)$}

Even built a windmill, even though then known not to be netherlandic but named after 'an architect and an amateur actor' (firstname: hugh). But with firstthought gummier than factis, who heeds dry whatwas? Whose holland then? Whose veridical? The market. The mandarin. The moment's manifold. Loudmusic next to lebanese. Chic cambodian incense atomised through airvents to burke bavarian brauhaus bouquet. The owner of original sin saying, en passant, I charge $\$ 18$ for a salad. How much more do you think I can raise prices just so the landlord can collect kpis. Thambi peddling streetcorner newsoftheworld, any tastescriptlayoutlanguage setting for as long as I can remember. This atmos. This brume. This 人气. This angin, without anger mostly, more freneticalm, a kind of determination to seenotsee, to stride past the faketouts and flagsellers en route to a facial. The justheretohaveagoodtimewhycannot tilt of the chin. A goto, not a from. A place pronow. 